\title{
A new species of Farlowella (Siluriformes: Loricariidae) from the upper Bermejo River, La Plata River basin, northwestern Argentina
}

\author{
Guillermo E. Terán ${ }^{1}$, Gustavo A. Ballen², Felipe Alonso³ Gastón Aguilera $^{1}$ and \\ J. Marcos Mirande ${ }^{1}$
}

A new species of Farlowella is described from the Bermejo River basin, in Salta and Jujuy provinces, northwestern Argentina. The new species belongs to the Farlowella nattereri species group. The new species is diagnosed by the following combination of characters: marbled rostrum, five rows of lateral plates series, relatively short snout (snoutmouth length less than $50.0 \%$ of head length), complete half-moon shaped spot on caudal fin, and short predorsal distance (37.8-41.8\% of standard length).

Keywords: Armored catfish, Chaco Ecoregion, Endemic species, Loricariinae, Taxonomy.

Se describe una nueva especie de Farlowella de la cuenca del Río Bermejo, en las provincias de Salta y Jujuy, en el noroeste de Argentina. La nueva especie pertenece al grupo de Farlowella nattereri. La nueva especie se diagnostica con la siguiente combinación de caracteres: rostro veteado, cinco hileras de placas laterales en el cuerpo, hocico relativamente corto (longitud hocico-boca menor a 50.0\% longitud cabeza), mancha en forma de media luna completa en la aleta caudal, y distancia predorsal corta (37.8-41.8\% longitud estándar).

Palabras clave: Ecoregion Chaco, Especie endémica, Loricariinae, Taxonomía, Viejita del agua.

\section{Introduction}

The armored catfish genus Farlowella Eigenmann, Eigenmann, 1889 is the second richest among the Loricariinae (Van der Laan et al., 2014) with 29 valid species (Fricke et al., 2019). Its species are easily recognized by the long and slender body, variably pronounced rostrum, and the dorsal-fin insertion set nearly halfway between the head and the tail (Covain, Fisch-Muller, 2007). Farlowella is widely distributed in the main cis-Andean South American River drainages (Orinoco, Amazon, and La Plata) and species of the genus are also found in the trans-Andean Maracaibo and Magdalena River basins (Ballen, Mojica, 2014). Retzer, Page (1996) proposed six distinct species groups of Farlowella (viz., the F. acus, F. amazonum, F. curtirostra, F. knerii, F. mariaelenae, and F. nattereri species groups). And, some species of uncertain relationships remain unassigned to any group (Tab. 1).

Farlowella hahni has been so far the only species reported from Argentina (Mirande, Koerber, 2015).
However, it has been suggested that the type locality of $F$. paranaense (currently a junior synonym of $F$. amazonum) is located in Argentina (see, Azpelicueta, Koerber, 2014). During recent expeditions to the upper Bermejo River basin in northwestern Argentina, specimens attributable to the $F$. nattereri species group were collected and are herein described as a new species.

\section{Material and Methods}

Measurements were taken point to point with digital caliper to the nearest $0.1 \mathrm{~mm}$, as straight lines between two points. Standard length (SL) is expressed in $\mathrm{mm}$ and all other measurements are expressed as percentages of SL, except subunits of the head, which are expressed as percentages of head length (HL). Terminology, meristics and measurements follow Ballen et al. (2016a). Meristics are reported followed by their frequencies in parentheses with an asterisk indicating the count of the holotype.

\footnotetext{
${ }^{1}$ Instituto de Vertebrados, Fundación Miguel Lillo; UEL-CONICET. Miguel Lillo 251, T4000JFE San Miguel de Tucumán, TU, Argentina. (GET) guilloteran@gmail.com, ○https://orcid.org/0000-0002-3795-3345 (corresponding author); (GA) gaguilera@lillo.org.ar, Dhttps://orcid.org/0000-0002-5486-2787; (JMM) mcmirande@gmail.com, Dhttps://orcid.org/0000-0003-4370-3526

${ }^{2}$ Museu de Zoologia da Universidade de São Paulo, Av. Nazaré, 481, Caixa Postal 42494, 04218-970 São Paulo, SP, Brazil. gaballench@gmail.com, Ohttps://orcid.org/0000-0001-5424-8608

${ }_{3}^{3}$ Instituto de Bio y Geociencias del NOA (IBIGEO)-CONICET, Av. 9 de Julio 14, CP4405 Rosario de Lerma, SA, Argentina. felipealonso@gmail.com, Dhttps://orcid.org/0000-0001-7227-2732
} 
Tab. 1. List of species and species groups of the genus Farlowella.

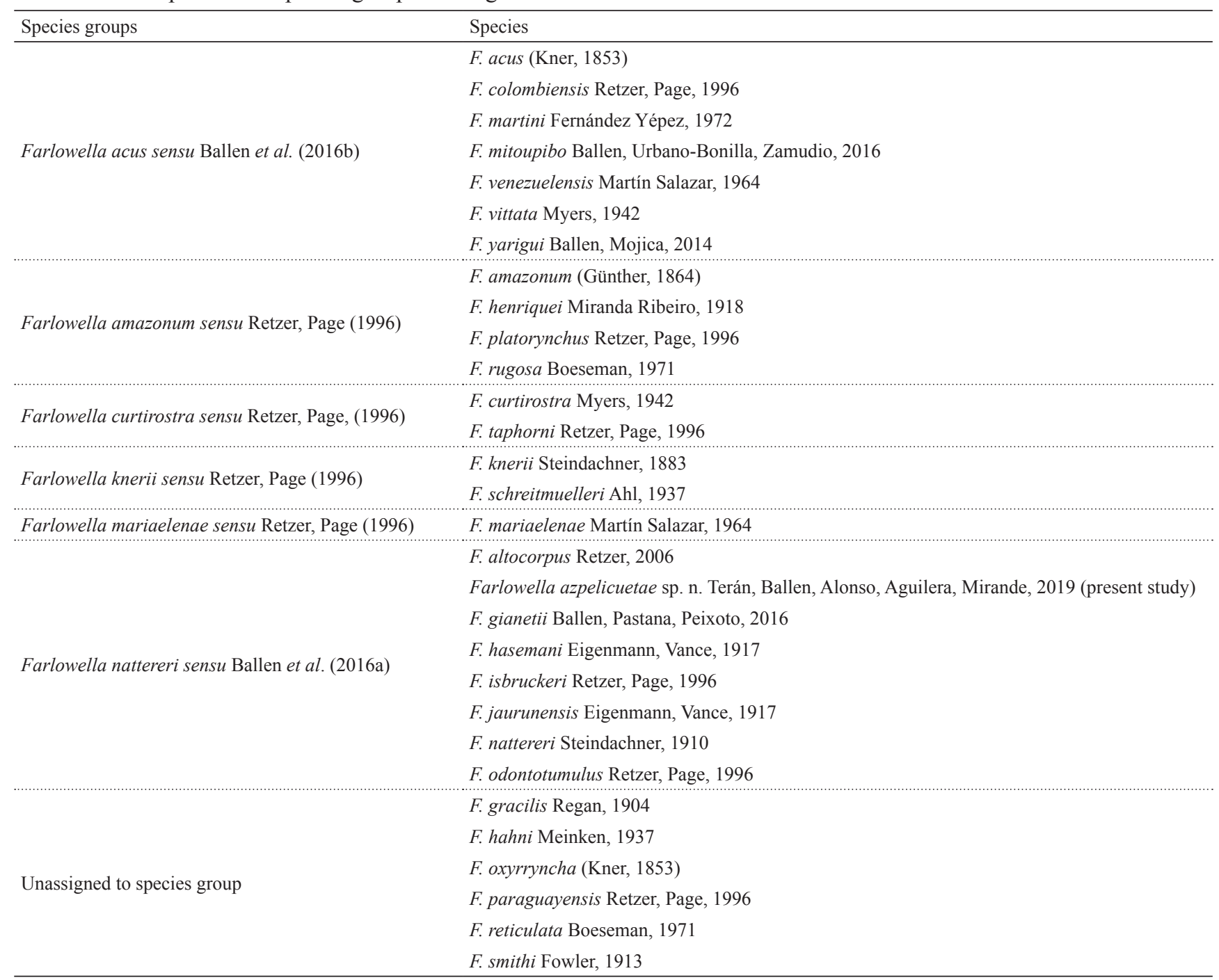

Specimens were euthanizated by immersion in solution of $0.1 \%$ 2-phenoxyethanol (King et al., 2005), fixed in a $10 \%$ formalin solution for 7 days, and then preserved in ethanol solution $70 \%$. Specimens were cleared and counterstained $(\mathrm{c}, \mathrm{s})$ following Taylor, Van Dyke (1985). The comparisons with Farlowella altocorpus, F. knerii, F. martini, F. odontotumulus, $F$. rugosa, F. taphorni and F. venezuelensis were done form their original descriptions and from posterior revisions (Steindachner, 1882; Martín Salazar, 1964; Boeseman, 1971; Fernández-Yépez 1972; Retzer, Page, 1996; Retzer, 2006). Institutional codes follow Fricke, Eschmeyer (2019).

\section{Results}

\section{Farlowella azpelicuetae, new species}

urn:1sid:zoobank.org:act:E8176E2F-F1B4-4998-A5BCAC11B9C151ED

Figs. 1-2, Tab. 2.
Holotype: CI-FML 7277, $142.3 \mathrm{~mm}$ SL. Argentina, Salta, Bermejo River, La Plata River basin, $23^{\circ} 10^{\prime} 56^{\prime \prime} \mathrm{S}$, $64^{\circ} 12^{\prime} 18.36^{\prime \prime} \mathrm{W}, c a .300 \mathrm{~m}$ above sea level (asl). 26 Sep 2015. G.E. Terán, G. Aguilera, F. Alonso and J.M. Mirande.

Paratypes. CI-FML 7265, 7 (2 c,s), 64.2- $193.8 \mathrm{~mm} \mathrm{SL}$; IBIGEO-I 453 6, 69.3-77.5 mm SL; MZUSP 123935, 1, $83.3 \mathrm{~mm}$ SL. Collected with the holotype. CI-FML 7274, 2, 72.3-178.7 mm SL; MZUSP 123936, 2, 169.0-81.4 mm SL. Argentina, Salta, Bermejo River basin, $23^{\circ} 10^{\prime} 56^{\prime \prime} \mathrm{S}$, $064^{\circ} 12^{\prime} 18.36^{\prime \prime} \mathrm{W}, c a .300 \mathrm{~m}$ asl. 20 Sep 2016. G.E. Terán, G. Aguilera, F. Alonso and J. M. Mirande. CI-FML 7266, 1, $140.9 \mathrm{~mm}$ SL; CFA-IC-8845, 2, 129.7-130.9 mm SL. Argentina, Jujuy, San Francisco River, Bermejo River basin, 2350'27.08”S, 64³7’24.70”W, ca. 370 m asl. 30 Sep 2016. G.E. Terán and G. Aguilera.

Diagnosis. Farlowella azpelicuetae differs from most congeners, except $F$. altocorpus, $F$. gianetii, $F$. gracilis, $F$. hasemani, F. isbrueckeri, F. jauruensis, F. nattereri, and $F$. 
odontotumulus, by the presence of five rows on lateral plate series of body (vs. four). Farlowella azpelicuetae differs from $F$. gracilis, F. hasemani, F. isbrueckeri, F. nattereri, and $F$. odontotumulus by having proportionally-shorter snoutmouth length (less than 50\% HL vs. more than 50\% HL). The new species differs from $F$. jauruensis and $F$. gianetii by its marbled coloration pattern of snout ( $v s$. snout completely dark and snout darkly pigmented only laterally, respectively). Farlowella azpelicuetae differs from $F$. altocorpus by having a continuous half-moon pigmentation pattern on the caudal fin ( $v s$. discontinuous half-moon shaped pattern) and by the shorter predorsal length (37.8-41.8 \% SL vs. 43.7-45.6\% SL). The new species can be further distinguished by the presence of three rows of abdominal plates (vs. two in F. acus, F. amazonum, F. colombiensis, F. henriquei, F. martini, F.rugosa, $F$. venezuelensis, $F$. vittata, and $F$. yarigui and an incomplete median disjunct row of abdominal plates in F. mitoupibo). Additionally, F. azpelicuetae differs from F. hahni, F. knerii, $F$. oxyrryncha, F. reticulata, and $F$. schreitmuelleri by having irregular dark brown blotches on the snout ( $v s$. a reticulated pattern formed by the dark pigmentation of the border of the bony plates in the head); from F. curtirostra and F. taphorni by the absence of breeding odontodes on side of head and presence of a long and slender snout ( $v s$. presence of breeding odontodes on sides of the head and presence of a short and broad snout). The new species also differs from $F$. hahni, $F$. mariaelenae, $F$. oxyrryncha, F. paraguayensis, and F. smithi by having a continuous half-moon pigmentation pattern on the caudal fin ( $v s$. caudal pigment restricted to the dorsal lobe in F. hahni, F. oxyrryncha, and F. smithi and discontinuous pattern with dark stripe in upper lobe of caudal fin broad and larger than stripe in lower caudal lobe in F. mariaelenae and $F$. paraguayensis). Additionally, the new species can be distinguished from $F$. gianetii by having i,11,i or i,12,i caudal-fin rays (vs. i,10,i), F. gracillis by the diamond-shaped plates in the second row of lateral plate series ( $v s$. hexagonal plates), from $F$. isbrueckeri by presenting the ventromedian row of anterior plates keeled and the marbled coloration pattern on snout (vS. row unkeeled and snout entirely dark), from $F$. jauruensis by having i,5 pelvic-fin rays (vs. i,4), from $F$. nattereri by first anal- and dorsal-fin rays not entirely darkly pigmented (vs. entirely pigmented), and from $F$. odontotumulus by the presence of spots on fins (vs. spines and rays lacking spots).

Description. Morphometric data for holotype and paratypes presented in Tab. 2. Body elongate, slender and cylindrical in transversal section, dorsoventrally depressed. Greatest body depth and width at opercular region. Head slightly depressed in lateral view, body trunk cylindrical, caudal peduncle depressed. Dorsal profile of head concave from snout tip to anterior margin of nares, relatively straight from that point to posterior margin of parieto-supraoccipital, and then slightly concave until dorsal-fin origin. Body profile straight from last dorsal-fin ray to caudal fin. Ventral profile slightly straight from tip of snout to pectoral girdle, straight from that point to anal-fin insertion; straight from the terminus of anal fin to anteriormost ventral caudal-fin plate.

Body completely covered with bony plates except for snout tip, gular region and oval region surrounding urogenital area. Snout short, papillae absent. Preorbital ridge present. Anterior and posterior nares of similar size, with dermal flap separating both openings.

Orbit dorsolateral, not visible in ventral view; iris operculum present. Sixth infraorbital present. Dorsal surface of head with longitudinal keel on supraoccipital bone; compound pterotic ornamented with reticulate pattern of perforations.

Mouth ovoid, lower lip longer than upper lip; wide oval papillae on upper lip and round papillae on lower lip; decreasing in size from oral aperture to lip margin; lip margin papillose. Few platelets anterior to lip. Each premaxilla with 21(1), 22(4), 23(1), 24(4), 25(4), 28(1), 29(1), 33(3), or $34 *(1)$ bicuspid teeth. Each dentary with 20(2), 21(3), 22(3), 23(3), 24(1), 25(4), 27(1), 29(1), 30*(1), or 33(1) bicuspid teeth; premaxilla wider than dentary. Buccal papillae present. Ventral surface of head completely covered by platelets. Two maxillary barbels small and projecting slightly from mouth margin.

Five lateral plate rows on anterior portion of body, dorsal series with $30(1), 31 *(12), 32(5), 33(1)$, or 34(1) plates; dorsomedian series with $7 *(9), 8(7)$, or 9(4) plates; median series with $7(1), 8^{*}(6), 9(6), 10(5)$, or 11(2) plates; dosomedian+median series with 4(1), 5(5), 6*(7), or 7(7) plates; ventromedian series with $15^{*}(7)$ or $16(13)$ plates; ventral series with $32(2), 33 *(6), 34(6), 35(5)$, or $36(1)$ plates; and coalescent series with $18(12), 19 *(6)$, or $20(2)$ plates.

Pectoral-fin rays $\mathrm{i}, 6^{*}(20)$, posterior border straight, leading ray longest and thicker than branched rays; pelvicfin rays i, $5^{*}(20)$, posterior margin slightly curved; dorsal-fin rays i, $6^{*}(20)$. Anal-fin rays i,5*(20), similar in size and shape to dorsal fin. Adipose fin absent. Caudal-fin rays i,11,i(2), $\mathrm{i}, 12, \mathrm{i}^{*}(18)$, dorsal and ventral lobes similar in size; the principal caudal-fin ray in each lobe bears a filament. Breeding odontodes were not found in the analyzed specimens.

Color in alcohol. Background coloration light brown, with one dark brown lateral stripe on each side, that runs from snout to end of dorsal fin, leaving a central light brown area (Fig. 1). Snout with dark brown marbled pattern in dorsal view (Fig. 2a), more uniform and darker in the ventral and lateral portions of head and lighter on the dorsal region. Ventral body region light brown with diffuse scattered pigmentation. Fins with dark brown blotches on rays and slightly hyaline on membranes. Caudal fin with a dark marking forming a continuous crescentic half-moon pigmentation pattern (Fig. 2b).

Color in life. Overall coloration of specimens in life similar to specimens after fixation except for the brighter yellowish background of the body (Fig. 2c). 
Tab. 2. Morphometric data of Farlowella azpelicuetae, sp. n. (n=20). SD, standard deviation. Range includes the holotype.

\begin{tabular}{|c|c|c|c|c|}
\hline & Holotype & Range & Mean & $\mathrm{SD}$ \\
\hline Standard length (SL) & 142.4 & $64.2-193.9$ & & \\
\hline \multicolumn{5}{|c|}{ Percentage of Standard length } \\
\hline Head length (HL) & 24.9 & $22.8-25.0$ & 23.8 & 0.8 \\
\hline Body depth at dorsal- fin origin & 5.9 & $5.4-6.4$ & 5.9 & 0.3 \\
\hline Body width at dorsal- fin origin & 6.6 & $6.4-8.1$ & 7.0 & 0.4 \\
\hline Body width at anal- fin origin & 7.0 & $5.5-7.6$ & 6.5 & 0.5 \\
\hline Predorsal length & 41.4 & $37.8-41.8$ & 39.7 & 1.1 \\
\hline Postdorsal length & 54.2 & $51.4-57.6$ & 54.7 & 1.6 \\
\hline Postanal length & 54.6 & $50.0-56.8$ & 53.9 & 1.6 \\
\hline Caudal peduncle depth & 1.5 & $1.0-1.5$ & 1.2 & 0.1 \\
\hline Dorsal-spine length & 16.9 & $15.4-17.2$ & 16.3 & 0.5 \\
\hline Pectoral-spine length & 13.8 & $12.5-14.2$ & 13.3 & 0.5 \\
\hline Pelvic-spine length & 8.9 & $7.7-9.0$ & 8.4 & 0.4 \\
\hline Anal-spine length & 16.1 & $14.4-16.1$ & 15.2 & 0.5 \\
\hline \multicolumn{5}{|c|}{ Percentage of Head Length } \\
\hline Snout length & 73.8 & $65.3-74.3$ & 69.6 & 2.7 \\
\hline Snout-mouth length & 41.3 & $26.9-43.5$ & 34.3 & 5.2 \\
\hline Eye diameter & 6.6 & $6.3-10.0$ & 7.7 & 1.1 \\
\hline Interorbital width & 19.8 & $19.6-23.8$ & 21.3 & 1.1 \\
\hline Head width & 36.9 & $34.7-43.0$ & 38.3 & 2.3 \\
\hline Head depth & 22.8 & $21.8-28.0$ & 24.5 & 1.9 \\
\hline \multicolumn{5}{|c|}{ Proportion characters sensu Retzer, Page (1996) } \\
\hline Snout-mouth length / pectoral-spine length & 74.4 & $48.9-77.8$ & 61.3 & 9.6 \\
\hline Snout-mouth length / HL & 41.3 & $26.9-43.5$ & 34.3 & 5.2 \\
\hline HL / Snout-mouth length & 242.3 & $229.8-371.3$ & 298.1 & 44.1 \\
\hline Body depth / pelvic-spine length & 65.9 & $63.1-78.9$ & 70.8 & 4.4 \\
\hline Pectoral spine length / snout-mouth length & 134.5 & $128.6-204.6$ & 166.8 & 25.7 \\
\hline Snout-mouth length / interorbital width & 208.1 & $121.5-218.2$ & 162.2 & 31.2 \\
\hline Body width / snout-mouth length & 64.4 & 64.4-111.9 & 87.3 & 14.2 \\
\hline
\end{tabular}

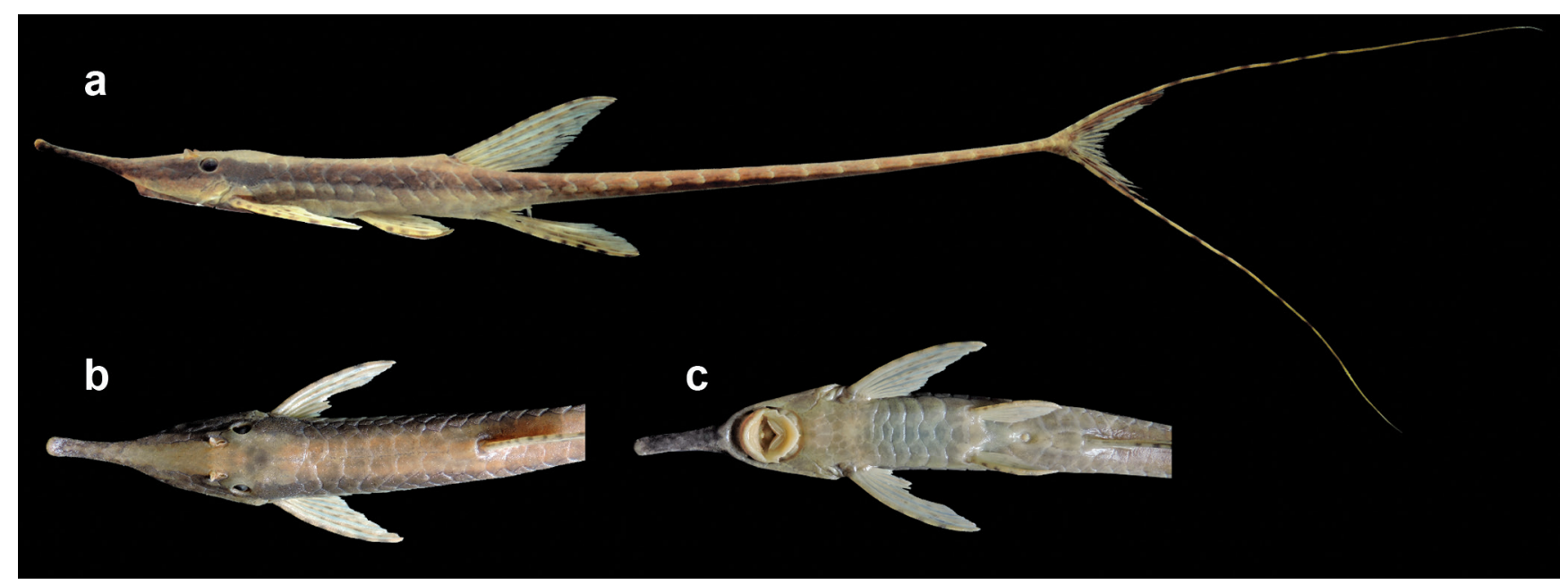

Fig. 1. Farlowella azpelicuetae, holotype, Argentina, Salta, Bermejo River, La Plata River basin. CI-FML 7277, $142.4 \mathrm{~mm}$ $\mathrm{SL}$, a. lateral, b. dorsal, and c. ventral views. 
Geographic distribution. Farllowella azpelicuetae is distributed in the upper Bermejo River basin, La Plata basin, provinces of Salta and Jujuy in the Yungas region, northwestern Argentina (Fig. 3).

Ecological notes. Specimens were collected at altitudes ranging from 310 to 450 masl in the main channel of the Bermejo (Fig. 4) and San Francisco Rivers, associated with wood drift debris on the margins. No specimens of this species were captured in streams, or small courses of water sampled in the area.

Etymology. The species is named azpelicuetae after Dr. María de las Mercedes Azpelicueta, in recognition of her prominent contributions to ichthyology, especially to the systematics of Argentinian fishes. She described numerous species and was essential to the formation of subsequent generations of freshwater fish systematists in Argentina. A matronym in genitive case.

Conservation status. Considering that no major threats to the species were detected in the area of distribution, the conservation status of Farlowella azpelicuetae may be classified as having Least Concern (LC), according to the International Union for Conservation of Nature (IUCN) categories and criteria (IUCN, 2017).

Comparative material. Most of the comparative material was listed in Ballen, Mojica (2014), Ballen et al. (2016a, 2016b). Additional material: Farlowella hahni: Argentina, Province of Corrientes, Paraná River, CI-FML 5419,1, 43.9 mm SL; CI-FML 7504, 3, 74.8-114.2 mm SL.

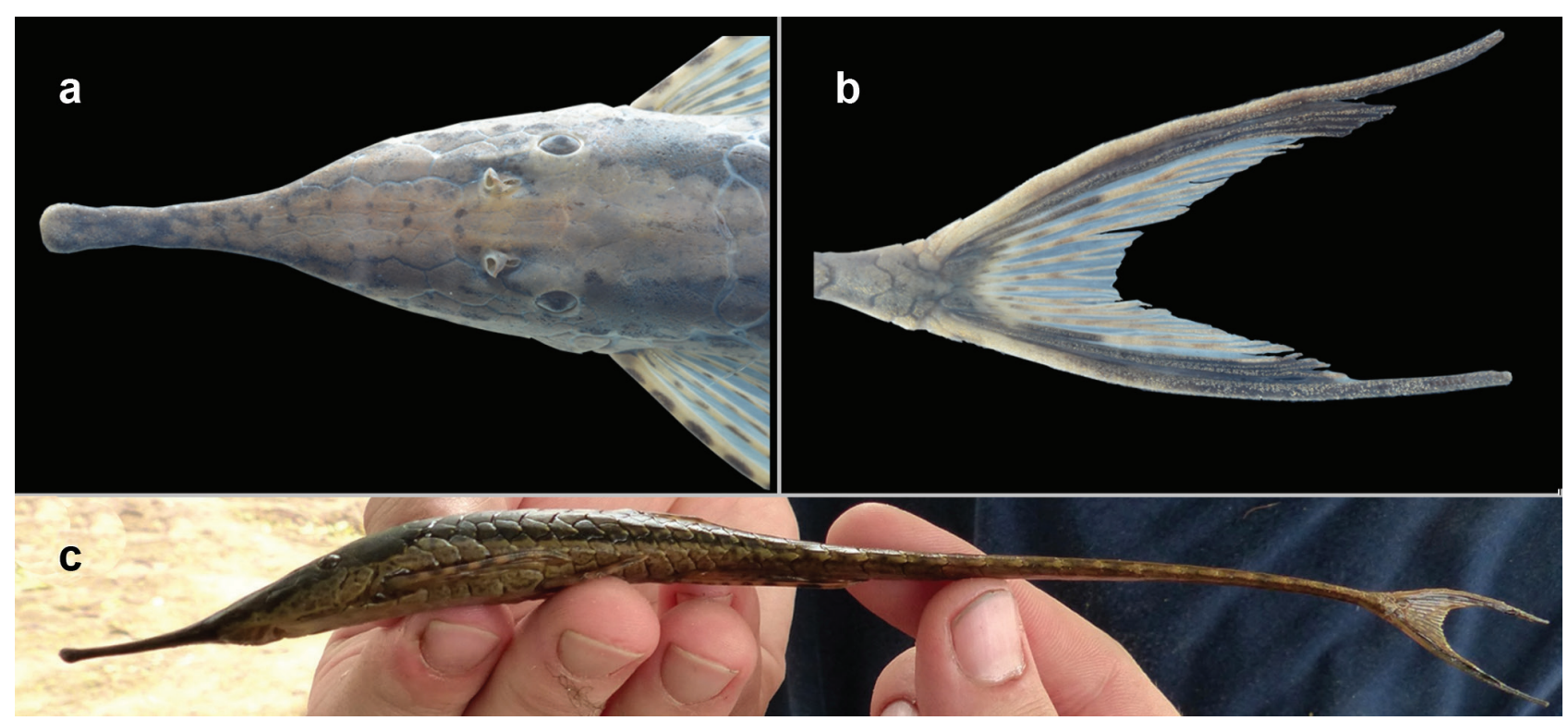

Fig. 2. Farlowella azpelicuetae, paratype, CI-FML 7265, $193.9 \mathrm{~mm}$ SL. a. detail of the coloration of the snout; b. coloration pattern of caudal fin; c. coloration of live specimen.

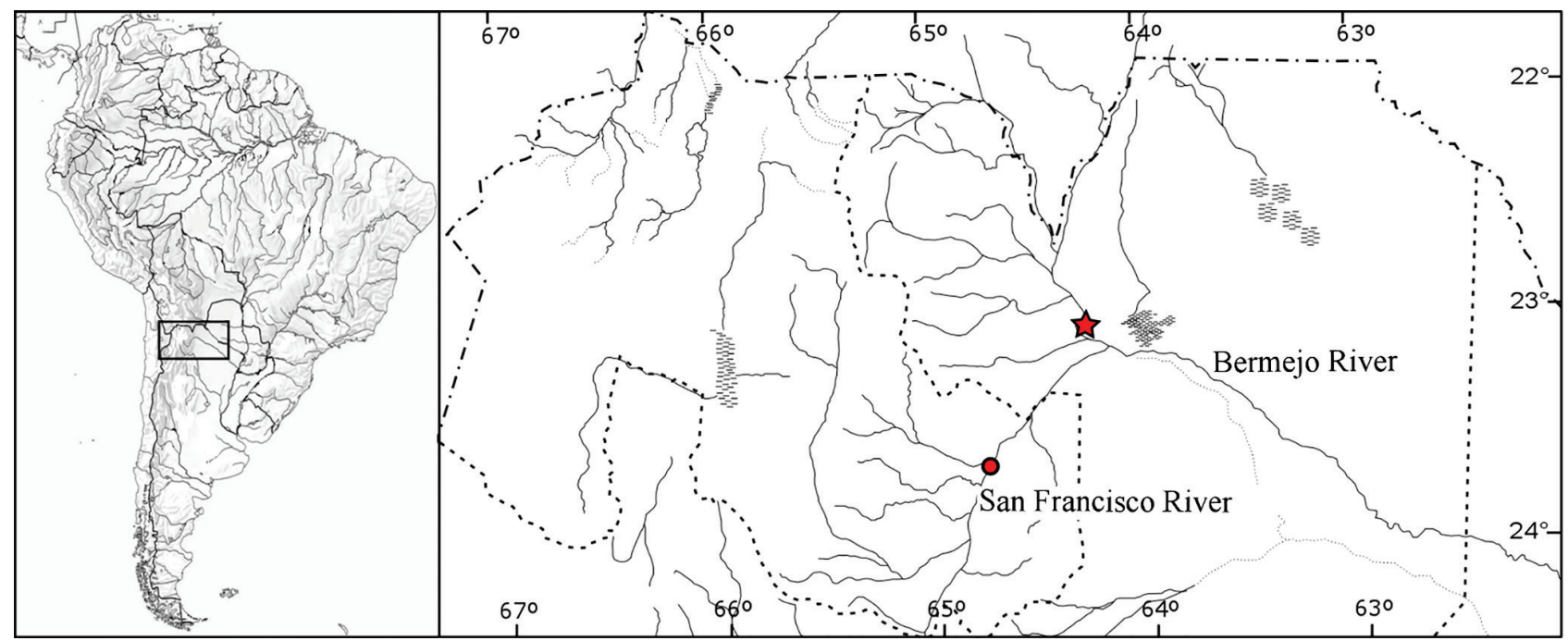

Fig. 3. Map of northwestern Argentina, showing the distribution of Farlowella azpelicuetae. Red star represents the type locality. 


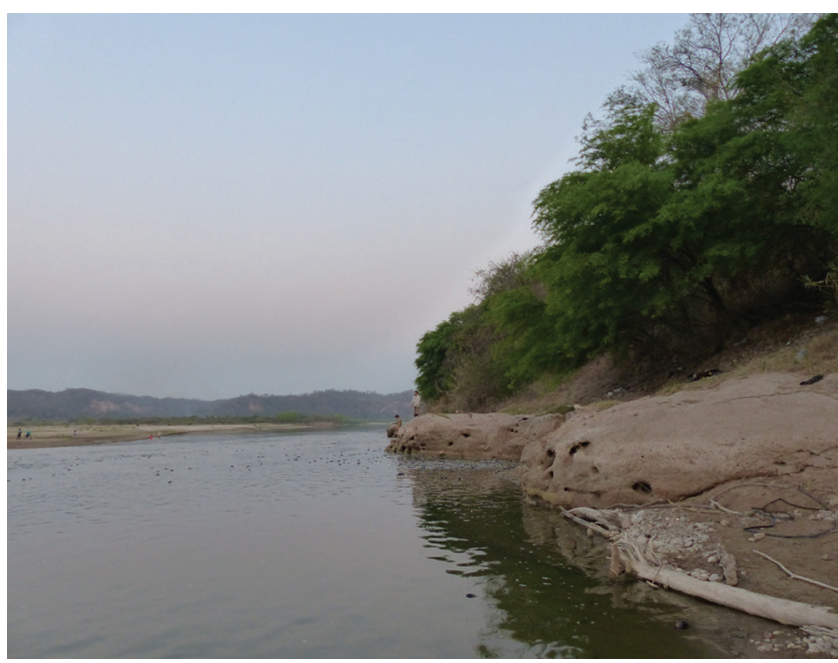

Fig. 4. Type locality of Farlowella azpelicuetae. Bermejo River at $23^{\circ} 10^{\prime} 56^{\prime \prime} \mathrm{S}, 64^{\circ} 12^{\prime} 18.36^{\prime \prime} \mathrm{W}$, La Plata River basin, Salta, Argentina. September 2016.

\section{Discussion}

Farlowella azpelicuetae is assigned to the Farlowella nattereri group sensu Ballen et al. (2016a) (see Tab. 1), because it exhibits the following characteristics: five lateral plates on the anterior portion of the body, three abdominal plate series, and diamond shaped median plates.

The new taxon is the second species of the genus Farlowella known to Argentina after F. hahni, distributed in the lower Paraná and Paraguay Rivers. A third species mentioned for Argentina is F. amazonum. However, the presence of this species has not been confirmed and it is only based on the hypothesized locality of the holotype of $F$. paranaense (synonym of $F$. amazonum), after a probable labelling error by Meinken (see, Azpelicueta, Koerber, 2014).

The Bermejo River is one of the greatest hydrographic systems of Argentina and one of the main tributaries of the Rio de la Plata system. According to Hales, Petry (2015), the Bermejo River basin belongs to the Chaco Ecoregion. This area also includes the drainages of the western Paraguay basin across Bolivia, Paraguay, and Argentina. There are presently more than 150 species of fishes recorded in this ecoregion of which at least 17 are endemic (Terán et al., 2016). The pace at which description of new taxa is occurring in this region suggests the chance of further discoveries. The outstanding diversity of the area when compared to other drainages in the southernmost portion of the continent renders the Bermejo River basin an important reservoir of biological resources for Argentina.

\section{Acknowledgments}

Financial support was provided by CONICET, Fundación Miguel Lillo, and FONCyT (PICT-2011-0992 and PICT-2016-0275 to JMM and PICT-2012-2683 to
GA). Secretaría de Ambiente of Salta and Jujuy provided the collecting licenses. GAB was funded through a doctoral scholarship and a BEPE internship grant by FAPESP (2014/11558-5 and 2016/02253-1). We thank Fabiana Cancino for the loan of material. This work was benefited by the comments of Priscila Camelier, Rafaela Ota, Sven Kullander and anonymous reviewers.

\section{References}

Azpelicueta MM, Koerber S. Finding of the holotype of Farlowella paranaense Meinken, 1937. Hist Nat (Buenos Aires). 2014; 4(2):95-99.

Ballen GA, Mojica JI. A new trans-Andean Stick Catfish of the genus Farlowella Eigenmann \& Eigenmann, 1889 (Siluriformes: Loricariidae) with the first record of the genus for the río Magdalena Basin in Colombia. Zootaxa. 2014; 3765(2):134-42. Available from: http://dx.doi.org/10.11646/ zootaxa.3765.2.2

Ballen GA, Pastana MNL, Peixoto LAW. A new species of Farlowella (Siluriformes: Loricariidae) of the $F$. nattereri species-group from the rio Xingu basin, Mato Grosso, Brazil, with comments on Farlowella jauruensis, a poorly-known species from the upper rio Paraguai basin. Neotrop Ichthyol. 2016a; 14(3):e160046. Available from: http://dx.doi. org/10.1590/1982-0224-20160046

Ballen GA, Urbano-Bonilla A, Zamudio JE. Farlowella mitoupibo, a new species of stick catfish from the upper Guaviare River, Orinoco basin, Colombia (Teleostei: Loricariidae). Ichthyol Explor Freshw. 2016b; 27(4):325-32.

Boeseman M. The "comb-toothed" Loricariinae of Surinam, with reflections on the phylogenetic tendencies within the family Loricariidae (Siluriformes, Siluroidei). Zool Verh. 1971; 116:1-56.

Covain R, Fisch-Muller S. The genera of the Neotropical armored catfish subfamily Loricariinae (Siluriformes: Loricariidae): a practical key and synopsis. Zootaxa. 2007; 1462(1):1-40. Available from: https://www.mapress.com/zootaxa/2007f/ zt01462p040.pdf

Fernández-Yépez A. Análisis ictiológico del complejo hidrográfico (04) "Río Yaracuy". Ministerio de Obras Públicas. Venezuela. 1972; 1:1-25

Fricke R, Eschmeyer WN, Van der Laan R. Eschmeyer's catalog of fishes: genera, species, references [Internet]. San Francisco(CA): California Academy of Sciences; 2019 [cited 2019 May 2]. Available from: http://researcharchive. calacademy.org/research/ichthyology/catalog/fishcatmain. asp

Fricke R, Eschmeyer WN. Eschmeyer's catalog of fishes: Guide to fish collections. [Internet]. San Francisco (CA): California Academy of Sciences; 2019. [cited 2019 Apr 25]. Available from: http://researcharchive.calacademy.org/research/ichthyology/ catalog/collections.asp

Hales J, Petry P. Freshwater ecoregions of the world (FEOW). 342: Chaco [Internet]. 2015. [cited 2018 Aug 28]. Available from: http://www.feow.org/ecoregions/details/342 
International Union for Conservation of Nature (IUCN). Standards and Petitions Subcommittee. Guidelines for using the IUCN Red List categories and criteria. Version 13 [Internet]. 2017 [updated 2017 Mar]. Available from: http:// cmsdocs.s3.amazonaws.com/RedListGuidelines.pdf

King W, Hooper B, Hillsgrove S, Benton C, Berlinsky DL. The use of clove oil, metomidate, tricaine methanesulphonate and 2-phenoxyethanol for inducing anaesthesia and their effect on the cortisol stress response in black sea bass (Centropristis striata L.). Aquac Res. 2005; 36(14):1442-49. Available from: https://doi.org/10.1111/j.1365-2109.2005.01365.x

Martín Salazar FJ. Las especies del genero Falowella de Venezuela (Pisces - Nematognathi - Loricariidae) con descripción de 5 especies y 1 sub-especies nuevas. Mem Soc Cienc Nat La Salle. 1964; 24(69):242-60.

Mirande JM, Koerber S. Checklist of the freshwater fishes of Argentina (CLOFFAR). Ichthyol Contrib PecesCriollos. 2015; 36:1-68. Available from: http://www.pecescriollos.de/ es/icp

Retzer ME. A new species of Farlowella Eigenmann and Eigenmann (Siluriformes: Loricariidae), a stickcatfish from Bolivia.Zootaxa. 2006; 1282(1):59-68. Available from: https:// www.mapress.com/j/zt/article/view/zootaxa.1282.1.6/24837
Retzer ME, Page LM. Systematic of the stick catfishes, Farlowella Eigenmann \& Eigenmann (Pisces, Loricariidae). Proc Acad Nat Sci Philadelphia. 1996; 147:33-88. Available from: https:// www.jstor.org/stable/4065027

Steindachner F. Beiträge zur Kenntniss der Flussfische Südamerika's (IV). Anzeiger der Kaiserlichen Akademie der Wissenschaften in Wien, Mathematisch-Naturwissenschaftlichen Klasse. 1882; 19(19):175-80.

Taylor WR, Van Dyke GC. Revised procedures for staining and clearing small fishes and other vertebrates for bone cartilage study. Cybium. 1985; 9(2):107-19.

Terán GE, Jarduli LR, Alonso F, Mirande JM, Shibatta OA. Microglanis nigrolineatus, a new species from northwestern Argentina (Ostariophysi: Pseudopimelodidae). Ichthyol Explor Freshw. 2016; 27(3):193-202.

Van der Laan R, Eschmeyer WN, Fricke R. Family-group names of recent fishes. Zootaxa. 2014; 3882(1):1-230. Available from: http://dx.doi.org/10.11646/zootaxa.3882.1.1

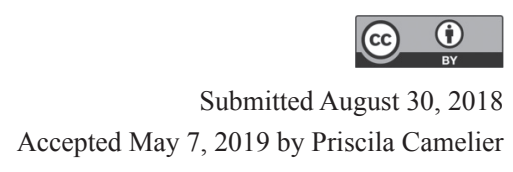


